\title{
Hestia: The Indo-European Goddess of the Cosmic Central Fire
}

\section{Marcello De Martino}

\begin{abstract}
The Pythagorean Philolaus of Croton (470-390 BCE) created a unique model of the Universe and he placed at its centre a 'fire', around which the spheres of the Earth, the Counter-Earth, the five planets, the Sun, the Moon and the outermost sphere of fixed stars, also viewed as fire but of an 'aethereal' kind, were revolving. This system has been considered as a step towards the heliocentric model of Aristarchus of Samos (310-230 BCE), the astronomical theory opposed to the geocentric system, which already was the communis opinio at that time and would be so for many centuries to come: but is that really so? In fact, comparing the Greek data with those of other ancient peoples of Indo-European language, it can be assumed that the 'pyrocentric' system is the last embodiment of a theological tradition going back to ancient times: Hestia, the central fire, was the descendant of an Indo-European goddess of Hearth placed at the centre of the religious and mythological view of a deified Cosmos where the gods were essentially personifications of atmospheric phenomena and of celestial bodies.
\end{abstract}

In 1960, an article came out in a scientific journal which specialised in topics which were a bit more eccentric that those of traditional research studies on the history of religions, especially the classical ones. Its title was On the Relation between Early Greek Scientific Thought and Mysticism: Is Hestia, the Central Fire, an Abstract Astronomical Concept?. ${ }^{1}$ The author was Rudolph E. Siegel, Assistant Professor at the State University of New York in Buffalo, an American university where I, myself, was a professor with similar qualifications from 1998-1999. I

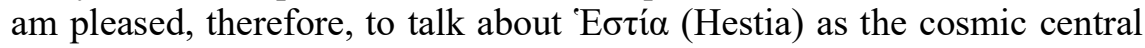
Fire, inspired by the writing of a scholar who is linked to the same

\footnotetext{
${ }^{1}$ R. E. Siegel, 'On the Relation between Early Greek Scientific Thought and Mysticism: Is Hestia, the Central Fire, an Abstract Astronomical Concept?', Janus. Revue internationale de l'histoire des sciences, de la médicine, de la pharmacie et de la technique, 49 (1960): pp. 1-20.

Marcello De Martino 'Hestia: The Indo-European Goddess of the Cosmic Central Fire', Culture and Cosmos, Vol. 23 no 1, Spring/Summer 2019, pp. 319. www.CultureAndCosmos.org
} 
academic institution as me even though he was an historian of medicine and not a specialist in classical world religions or (Pythagorean) philosophy. The original article dealt with the particular representation of the astronomical system of the Pythagorean ${ }^{2}$, Philolaus of Croton (470$390 \mathrm{BCE})^{3}$, which appears to be unique when placed among the different theoretical representations of the universe; indeed, it can rightly be called 'pyrocentric', namely fire-centred, unlike geocentric and heliocentric. It is in opposition to these representations, as it does not foster the belief, that at the centre of the Kosmos, there was the Earth or the Sun, but rather there was a 'fire', around which 10 celestial spheres revolved in a progression of the distance (from it) which was related to factors of 3, considered a sacred number by Pythagoreans. ${ }^{4}$

Siegel's article intended to prove that the so-called 'Central Fire' by Philolaus was not 'a material, extended body occupying the central space of the cosmos', but, in reality, was 'the geometrical centre, the focal point of the universe'. ${ }^{5}$ The hypothesis of the American scholar was that the Pythagorean of Croton would try to use geometric concepts to simplify astronomical laws, imagining, ultimately, a theory innovative as well as destabilising for its time, having the aim of supplanting the geocentric system accepted by Pythagoras and his school. ${ }^{6}$ In doing so, Philolaus would have borrowed some mystic traditions by fanning the religious feelings of his contemporaries in order to 'cover', with a more acceptable mantle of sacred tradition, the revolutionary idea of Earth as a planet, that is, a moving celestial body. If it is quite likely that the pyrocentric system of Philolaus had, as its goal, to elucidate, in a more reasonable way, from a purely geometrical point of view, some astronomical phenomena of indubitable intricate interpretation, if placed in a geocentric perspective, then it seems reductive to explain some

${ }^{2}$ On Pythagorean astronomy see B. L. van der Waerden, Die Astronomie der Pythagoreer (Verhandelingen der Koninklijke Nederlandse Akademie van Wetenschappen, Afd. Natuurkunde, Eerste Reeks, Deel XX, No. 1) (Amsterdam: North Holland Publishing Company, 1951).

${ }^{3}$ See C. A. Huffman, Philolaus of Croton: Pythagorean and Presocratic (Cambridge: Cambridge University Press, 1993).

${ }^{4}$ P. Kucharski, Étude sur la doctrine pythagoricienne de la Tétrade (Paris: Société d'Édition 'Les Belles Lettres', 1952); A. Delatte, Études sur la littérature pythagoricienne (Paris: E. Champion, 1915), pp. 249-68 (cap.: 'La tétraktys pythagoricienne').

${ }^{5}$ Siegel, 'On the Relation', pp. 2-3.

${ }^{6}$ L. Zhmud, Pythagoras and the Early Pythagoreans (Oxford: Oxford University Press, 2012).

Culture and Cosmos 
symbols adopted by the Pythagoreans. I believe, in agreement with what Walter Burkhardt said ('mythology in scientific clothing'), that Philolaus had tried to give a 'scientific' covering to those mythological traditions which believed in a Central Fire in the Kosmos-Mundus; in my opinion, it is likely that Philolaus was the only one in historical times to re-actualise a very old astronomical system dating back to the prehistoric IndoEuropean period which was mirrored in an equally primitive ancestral pantheon where gods possessed a strong astral feature as they were, in fact, the theological product of such a pyrocentric system [author's italics]. I will analyse, then, the evidence that the classical tradition gives us relative to the 'new' astronomical theory of this Pythagorean of the second generation - the theory that, in hindsight, has proved to be very ancient!

As was the case for a good part of the classical authors of ancient times, from Philolaus, we received no written work concerning the doctrines which he had worked out in the various fields of knowledge of his chosen interest, of which we have rather meagre testimony of authors who lived in his time; this fragmentary documentary corpus has been thoroughly investigated, and the high level of science of these scholars we praise, nevertheless, we must note a total lack of any desire to actually make a comparison with similar sacred works of other Indo-European religions, such as Maria Timpanaro Cardini ${ }^{8}$ or Carl A. Huffman ${ }^{9}$ did, or to view the Philolaus data through the prism of a linguistic and intercomparative method, which, although commendable for their era, is woefully inadequate, as was the case with Thomas Henri Martin. ${ }^{10}$ All this is very regrettable inasmuch as it can be seen as counterproductive in the

7 W. Burkert, Lore and Science in Ancient Pythagoreanism (Cambridge, Massachussets: Harvard University Press, 1972), p. 342.

${ }^{8}$ M Timpanaro Cardini, M., Pitagorici. Testimonianze e frammenti. II. Ippocrate di Chio, Filolao, Archita e Pitagorici minori (Florence: La Nuova Italia editrice, 1962).

9 C. A. Huffman, 'Philolaus and the Central Fire', in S. Stern-Gillet and K. Corrigan (eds.), Reading Ancient Texts. Volume I: Presocratics and Plato. Essays in Honour of Denis O'Brien (Leiden: Brill Academic Publishers, 2007), pp. 57-94.

10 Th. H. Martin, 'Hypothèses astronomiques de Pythagore et de Philolaus', Bullettino di bibliografia e di storia delle scienze matematiche e fisiche Vol. V (1872): pp. 127-158; Th. H. Martin, 'Mémoire sur la signification cosmographique du mythe d'Hestia dans la croyance antique des Grecs', Mémoires de l'Académie des inscriptions et belles-lettres, Vol. XXVIII, first section (1874): pp. 1-23. 
time of hermeneutics, frustrating any ambition to put forward proposals for interpretative schemes marked by a religious perspective broader than that of ancient Greek.

First of all, we must take into account the passage from Stobaeus which affirmed 'the first harmonically composed, the One, in the middle of the sphere called hestia' which turns out to be a dry summary of the whole cosmology of the Pythagorean Crotoniate; it is said that the Unity, which is 'even-uneven' ( $\dot{\alpha} \rho \tau \imath \mathrm{c} \varepsilon \dot{\varepsilon} \rho \imath \tau \mathrm{c}$ ) as an agreement or 'harmony' of the two principles of even (unlimited) and odd (limited), is the medium which is the centre of the celestial sphere. ${ }^{11}$ Philolaus, therefore, believed that the Unity, or Monad, which is the basic concept of Pythagorean mathematics, was the foundation of the Kosmos-Mundus and was, therefore, at the centre of it, as is confirmed by another witness, this time, Iamblichus: 'The Monad, as it is the principle of all things according to Philolaus (in fact, doesn't he call it "the One principle of all things"?) [author's italics]'. ${ }^{12}$ These fragments attest to the eminently practical aim of Philolaus: to explain the physical universe according to criteria and geometric patterns referring to the Pythagorean theory of numbers. It is relevant that he would use, in this particular context, the term $\dot{\varepsilon} \sigma \tau i \dot{\alpha}$ meaning 'hearth'. This choice necessarily came from a theological background that would allow such a definition for the 'medium-centre' of the Cosmos - in short, the Pythagorean astronomer already had notions of a goddess, Hestia, as the centre of the Universe [author's italics].

Having said that, let's go then to the field of mythological thought on the Philolaic cosmological doctrine. In order to be of interest to this research, however, we have to recognise therein, at least, a clue about a possible Indo-European character.

In another passage of the Anthologium, Stobaeus shows the material constitution of the celestial sphere: 'The bodies of the sphere are five: those inside the sphere, that is, fire, water, earth and air, and the

${ }^{11}$ Stobaeus, Anthologium, Eclogae I, 21, 8, 2-3. The original Greek, from which

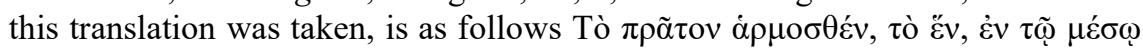

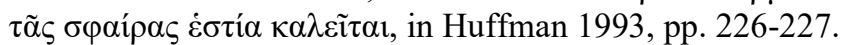

12 Iamblichus, Nicomachi arithmeticam introductionem 77, 9-11. Translation is

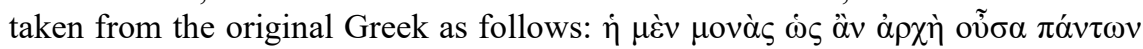

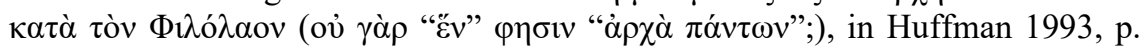
345.

Culture and Cosmos 
cargo ship of the sphere, as the fifth ${ }^{13}$ The unexpected term ó $\lambda \kappa \alpha$ 's has sparked many possible hypotheses from scholars creating a real crux interpretum that was solved by Ulrich von Wilamowitz-Moellendorff ${ }^{14}$ with the emendation ó $\lambda \kappa o ́ v$ which literally means 'drawing to oneself', but with an emendated value of volumen Ueberzug that actually makes the passage even more obscure, if that is at all possible. In fact, as the above-mentioned text shows, for Philolaus, there would have been five (!) elements in the celestial sphere, the fifth of which was called ó $\lambda \kappa a ́ s$ [author's italics]. After the conjecture of Wilamowitz-Moellendorff, accepted by Diels and Kranz, according to which the fifth element was to be the aether or quintessence, the Italian scholar, Maria Timpanaro Cardini, in her esteemed work on the edition of the ancient Pythagoreans that expanded on that of Diels and Kranz, came to understand, based on acute observations proposed by Zeller and Mondolfo on the close correlation between elements and polyhedra ${ }^{15}$, that the Philolaus' fragment quoted by Stobaeus was similar to the one reported by Aetius concerning the polyhedra. In doing so, it was possible for her to state that the ó $\lambda \kappa \alpha$ s indicated the dodecahedron, the solid form that seemed to come closer to that unreachable sphere and that contained, in itself, the solid forms attributed to the other four elements.

Is it therefore justified to assume that the Philolaic pyrocentric system, where the central fire was placed at the centre of the celestial Cosmos, but not on earth (considered a planet the same as the other five), had an Indo-European legacy [author's italics]? Indeed, the only difficulty in choosing this option is its historical incongruity related to the evolution of scientific thought as we would hesitate to attribute to people with a 'primitive' mind-set, as is commonly believed for the Indoeuropeans, an astronomical vision so advanced and/or complex from

\footnotetext{
13 Stobaeus, Anthologium, Eclogae I, 3, 27-29. Translation from Greek is as

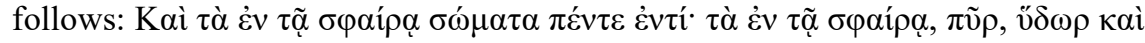

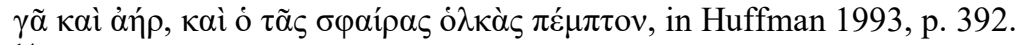

14 U. F. von Wilamowitz-Moellendorff, Platon, II. Beilagen und Textkritik (Berlin: Weidmann, 1920): pp. 91-92; a discussion on this passage is in M. Timpanaro Cardini, (ed.), Pitagorici. Testimonianze e frammenti. II. Ippocrate di Chio, Filolao, Archita e Pitagorici minori (Florence: La Nuova Italia editrice, 1962), pp. 100-102, with whom we agree.

15 H. Diels, and W. Kranz, Die Fragmente der Vorsokratiker, I-III (Berlin: Weidmann 1951-19526); Timpanaro Cardini, Pitagorici, pp. 100-02; and, E. Zeller and R. Mondolfo, 'Sulla questione degli elementi e dei poliedri regolari', in M. Isnardi Parente (ed.), La filosofia dei Greci nel suo sviluppo storico, I, vol 2 (Florence: La Nuova Italia, 1950), n. 1 at pp. 512-14.
} 
the point of view of logical-mathematics. This objection, mainly based on an a priori conviction of the alleged intellectual inadequacy of the 'primitive' Indo-European, encounters contradictions which are more apparent than objective. In reality, there is no need to believe that, in the Neolithic period, there was a sort of mathematician or astronomer in the same way as there was a Pythagorean such as Philolaus (!). However, it is more probable to assume, for the more intellectually vibrant representatives of this prehistoric community, such as was the IndoEuropean, a 'normal' vis imaginativa ${ }^{16}$ - to borrow a term of Marsilio Ficino - able to imagine the sky with its bright various phenomena, such as twilight, day and night, like a pantheon inherently structured and orderly (Kó $\sigma \mu \mathrm{o} \varsigma=$ 'order') [author's italics] according to the usual options available within the different human parental bonds: paternity/maternity versus filiation, brotherhood versus sisterhood, monogeniture versus twinship, marriage versus celibacy. No spherical trigonometry, such as that of Hipparchus of Rhodes (185-127 BCE) then, but only in mythology and theology would there be reference to astronomical beliefs of the prehistoric ancestors of the Greeks [author's italics]; although it has not been ruled out, being entirely natural, that these Indo-Europeans were able to advance an explanatory hypothesis, which could also be strong, about the formation of the terrestrial and celestial world, since they were, in the end, representatives of Homo Sapiens Sapiens with brains very similar to their more 'civilised' historical descendants who accomplished the so-called Greek miracle in the regions facing the basin of north-eastern Mediterranean. Apart from the complex Zodiac chart or of fixed stars, there is no doubt that the ancients were aware, even in periods previous to those of the historical civilizations, of the movement of celestial bodies such as the planets and, especially, one of the luminaries (although, being the orbit of the Sun around the Earth is apparent), which is quite clear. The sky above us was populated by gods from different cultures, whereas the Earth has always been populated by men and, therefore, it is obvious that to a 'primitive' way of thinking, every change of the heavenly state should correspond to a different divine will: indeed, the astrological thought encompasses all of itself into this simple concept.

One cannot discern anything for sure about the real astronomical knowledge of the prehistoric ancestors of several ancient Indo-European ethnic groups, but it is logical and probable that they had watched with

${ }^{16}$ For more on vis imaginativa, see Benassi, S., Marsilio Ficino e il potere dell'immaginazione, in "I castelli di Yale", II (1997), pp. 1-18. 
interest while probing the sky (as testified - if ever it were needed for these mere platitudes - by the well-known divine onomastic series

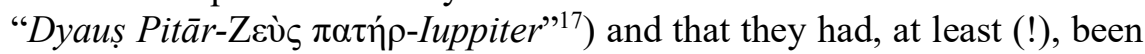
aware of the major 'planetary' revolutions, that is the (apparent) one of the Sun and the other of the Moon. We must think that to a theological and mythological concept derived from observations of these cosmic phenomena could be added some speculation about cyclical time, for example, the changes of seasons, the life cycle of birth and death, and other similar natural processes - in short, a kind of reflection that turns out to be universal from the socio-anthropological point of view. In this regard, it will be remembered that the discipline called ethnomathematics has proven beyond doubt that a high degree of logical complexity can be attained by a group of people or individuals in a social and anthropological context in which they have long been defined by the biased and wrong term 'primitive'. This being the case, it is thanks to the work of comparison with the mythologies and theologies of other ancient linguistically-related ethnic groups, that one is led to believe that the Philolaic perspective of the Cosmos was not then an isolated case inside that alleged 'primitive' Indo-European thought [author's italics]. Thus, we finally enter the field of interreligious comparison.

As is known, the fire god in the ancient Indian pantheon is called Agni, theonym of unequivocal Indo-European origin, which is related to the Latin. ignis, the Russian. огонь, the Polish ogien, the Slovanian, ogenj, the Servian-Croatian, oganj, the Lithuanian, ugnis, and the Lativian, uguns, all with the meaning of 'fire', whose reconstructed protoform was ${ }^{*} h_{1}$ ng $^{\mathrm{w}}$ ni- ${ }^{18}$ This deity was, after Indra, the most celebrated in the earliest periods of the religious Indo-European culture of the Indian subcontinent, as it is at the top of the list of deities to whom were dedicated hymns of the Rg Veda, the oldest corpus of sacred Hindu writings, with over 200 hymns dedicated to Agni. ${ }^{19}$ The sacral, mythological, and religious spheres of this god are very complex so we will limit ourselves here to consider only part of his characteristic features.

${ }^{17}$ F. M. Müller, 'The Lesson of Jupiter' in F. M. Müller (ed.), Anthropological Religion. The Gifford Lectures delivered before the University of Glasgow in 1891 (London: Longmans, Green and Co., 1892), p. 82.

18 J. Pokorny, J., Indogermanisches etymologisches Worterbuch I (Bern: Franke 1959), p. 293.

${ }_{19}$ Rig-veda. Ubersetzt und mit kritischen und erlauternden Anmerkungen, I, trans. H. Grassmann, (Leipzig: F. A. Brockhaus, 1876); II, 1877.

Culture and Cosmos 
10 Hestia: The Indo-European Goddess of the Cosmic Central Fire'

The birth of Agni is triadic, as is clearly stated in the first couplet of the 45th hymn in 'Book X' of the Rg Veda:

Divas pari prathamam jajñe agnir-asmad dvitīyam parijātavedāh $\mid 1 \mathrm{a}$ tṛtīyam-apsu nṛmañā ajasram-indhāna enam-jarate svādhīh $\| 1 \mathrm{~b}$

First Agni is born from heaven; the second time, 'the one who knows all of the creatures' came from us; and, thirdly, 'the Manly-souled' was in the abyss. The pious lauds and kindles him as perennial. ${ }^{20}$

The meaning is clear: the three birthplaces of fire are aerial, terrestrial, and aquatic, encompassing the entire Cosmos in its four fundamental elements; but the significance of these igneous generations is much more profound. The last birth of the god is that from his rising oceanic abyss which suggests the time when the sunlight comes up on the sea horizon, as we will determine soon, whereas his second coming to the world is the one of Agni as sacrificial fire controlled by brähmanās priests, which is a very significant aspect of the igneous element. The first and most important of the fire god births, however, is the one that occurrs in heaven, where the allusion to the lightning strike is clear: do not forget, in fact, that the first human contact with fire was through the combustion of inflammable items, such as trees and their like, implemented through the powerful electrical discharge of lightning. The exclusive naturalatmospheric aspect that characterises the three generations of the Vedic god of Fire is confirmed by family relations, which indicate that Agni was believed to be the son of Prth(i)vi, the Earth, and he had a sister Ușas, the Dawn. His father was Dyaus Pitār, the Indian counterpart of the Greek Zev̀ $\pi \alpha \tau \eta \dot{\rho} \rho$, Latin, Iuppiter, Norse, Týr, etc., all descendants of a primordial 'Shining Sky Father': *Dyēws Ph ${ }_{2}$ tēr, whose Indian successor had become an idle god or deus otiosus having bequeathed his IndoEuropean qualification of 'god of Lightning' (which is still attested to in

${ }^{20}$ The translations from Sanskrit are mine; the vedic text is in Th. Aufrecht, Die Hymnen des Rig Veda, $2^{\text {nd }}$ ed., Vol. II, Bonn 1877, p. 335, nonetheless, see R. T. H. Griffith (editor), The Hymns of the Rigveda, translated with a popular commentary Vol. 1 (Benares: E. J. Lazarus, 1889); R. T. H. Griffith (editor), The Hymns of the Rigveda, translated with a popular commentary, Vol. 2 (Benares: E. J. Lazarus, 1890).

Culture and Cosmos 
the Vedic literature, although as a vestige) to his son, Indra, the Agni twin. In short, the fire god of the Hindu religion was born from the god, 'Daytime Sky'; in other words, out of the generative metaphor, he was a deity who was within the heaven, as he was within the earth when he was born in a sacrificial actor status [author's italics]. There it seems that the analogy with the Pythagorean-Philolaic Hestia, the inflamed central place of the celestial sphere, and the Ovid Vesta, considered 'the same thing of the earth'(Fasti VI, 267: 'Vesta eadem est et terra') is very strong. ${ }^{21}$ In hindsight, there appropriately came aid to overcome the aforementioned impasse between a pyrocentric and geocentric vision of the sacred fire ultimately, the latter would have been seen at the 'Centre' of the MundusKosmos when it was viewed as the perennial heat engine or the inextinguishable propellant energy whose destructive force was represented by the 'aethereal fire' of lightning, whereas the same igneous element was considered the 'Centre' of the Earth (something like a 'geopyrocentric' system) when it takes place in its 'emic' tract of sacredness in the role of the operator of sacrifices for human beings, as it was for the sacred fire guarded in the adytum of the Apollo sanctuary at Delphi or its Latin counterpart preserved near the penus of the Aedes Rotunda Vestae in Rome. It should be emphasised that the nexus, 'ajasram-indhanna', appears in the centre of the couplet which I have analysed, having two terms of which the first, ajasra, has a meaning of 'inextinguishable' (privative $a$ - plus jas-, see jasati 'run out'), whereas the second, indhāna, is a derivative of the root with nasal infix in $(n) d h-$, (see inddhe 'turn on', pass. idhyate 'be kindled') and is coradical of Greek words, ai $\theta \omega$ 'burn',

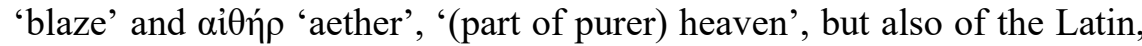
aestas, 'summer', 'summer heat', and aedes, 'small building (with fire)'. The latter item, along with those used to indicate the flame of the hearth, ('focus perennis'22) brings us directly both to the fire always 'vivid' ('vigil ignis ${ }^{23}$ ) of Vesta and to the Aedes Rotunda of the goddess in which it was kept in Rome.

The three couplets 3-5 of the same hymn will dispel all doubts about the divine atmospheric 'kin' of the Indian fire god Agni:

samudre tvā nrmaṇa apsv-antar-nrcakșā $\bar{\imath}$ dhe divo agna-ūdhan $\mid 3 \mathrm{a}$

\footnotetext{
${ }^{21}$ Ovid, Fasti VI, 267, in Frazer 1929, Vol. I, p. 316.

${ }^{22}$ Martial, Epigrammaton X, 47, 4, in Marco Valerio Marziale, Epigrammi, a cura di G. Norcio (Torino, UTET 2013), p. 619.

${ }^{23}$ Ovid, Fasti VI, 267, in Frazer 1929, Vol. I, p. 316.
} 
12 Hestia: The Indo-European Goddess of the Cosmic Central Fire'

\author{
akrandad-agni stanayann-iva dyauh kṣāmā rerihad vīrudhah- \\ samañjan $\mid 4 \mathrm{a}$ \\ sadyo jajñ̄anno vi hīm-iddho akhyad-ā rodasī-bhānunā bhāty- \\ antah $\| 4 \mathrm{~b}$ \\ vasuḥ sūnuh sahaso apsu rājā-vi bhāty-agra uṣasām- \\ idhānah $\| \mathrm{b}^{24}$
}

You, Agni, 'the Manly-souled' lit thee in ocean and waters, 'man's Viewer' in the breast of heaven

Agni roared as Dyaus thundered: he licked the earth devouring plants.

On the same day, just born, he looked around enkindled, and lightened heaven and earth in all its splendour.

Good son of strength, a king amid the waters, in forefront of the splendour of the Dawns, you are enkindled.

The first verse of the third couplet is very precise in regard to places, respectively, of the third and first birth. With regard to the aquatic generation of Agni, further specification is given in the last verse of the fifth couplet, when one says that, when he is kindled in the waters, of which he is the king, the fire god is at the forefront (-agra) of the light

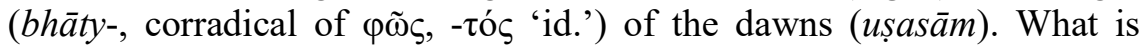
more important is the confirmation that the primordial characteristic of the Indian deity is the heavenly one: he was in the breast (ïdhan) of heaven (divo) and from there fell to the earth like lightning with the same roar of a 'stanayann- Dyauh'. This is a Sanskrit expression that is very useful for religious comparative purposes because the attribute of the Vedic god, being a morpheme derivative (causative) from the Sanskrit verb stan-ati, which is corradical (after the addition of the so-called IndoEuropean s-mobile) of Latin ton-äre, requires us immediately to make the comparison with the Roman god, Iuppiter, qualified as 'tonans', as found in the phrase 'Iove fulgurante comitia populi habere nefas' reported verbatim by Cicero from the commentarii of the college of augurs in his De divinatione II, 42-43. ${ }^{25}$ In fact, far from being an idle god or a Supreme Being as of that in primitive societies, Dyaus Pitār is represented during the day the same way as a red steer, whose bellow is

${ }^{24} \operatorname{Rg}$ Veda X, 45, 3a, 4ab, 5b, in Th. Aufrecht, Die Hymnen des Rig Veda, $2^{\text {nd }}$ ed., Bonn 1877, Vol. II, p. 335.

${ }^{25}$ Cicero, De divinatione II, 42-43, in Marco Tullio Cicerone, Della divinazione, a cura di S. Timpanaro, Milano 19984-2008, p. 143. 
compared to thunder ('Let Dyaus, the red steer, bellow his thunder downward' [avosriyo vrșabhah krandati dyauh]), and is connected to the lightning ("make room, Dyaus, to the jumping of the lightning" [dyaur dehi lokam vajrāya viṣkabhe]), whereas, as nocturnal sky, he takes the shape of a black horse adorned with pearls symbolising the stars' (abhi śyāvam na kriśanebhir aśvam nakṣatrebhih pitaro dyām apimśan).$^{26} \mathrm{In}$ one case, however, the god is depicted with a Blitzstein (aśanimām iva dyaur, where the term aśanimat literally means 'possessor of stone (aśan)-lightning'). ${ }^{27}$ As one can see, this Vedic deity has a particular characteristic, that is the atmospheric element of electricity, which makes him close to the Roman Iuppiter and the Greek Zev́s, a distinctive feature which, therefore, could also be supposed even for their divine ancestor of the common Indo-European period [author's italics]; therefore, it follows indubitably that the ancient Indian religious tradition took for granted the cause of origin of the fire in natural electricity: further confirmation can be seen in other Vedic hymns, such as in the 45th of Book X, where the second verse of the eighth couplet states that 'Agni became immortal by vital powers when Dyaus with the good seed begat him' (agnir-amrto abhavad vayobhir-yad-enam dyaur-janayat suretäh) [author's italics] ${ }^{28}$.

Given that, we have established the heavenly origin of the Indian fire god, Agni, and that we have also secured the intimate connection between the original god of Lightning, Dyaus Pitār, - a very important datum that is parallel to the close connection between 'Eotía, Zev́ $\varsigma$ and the sacred fire; so, it is necessary to identify, in order to justify the legitimacy of this Greek-Latin-Indian interreligious comparison, also the exact place in the sky where the said-divine fire was placed: in fact, the 'emic' traits that characterise the Indo-European theology concerning the sacred fire are the 'Centre' and the 'Circularity' and, if it is true that the flame of Agni is the same from the point of view of the sacredness of

${ }^{26} \operatorname{Rg}$ Veda V, 58, 6d, in Th. Aufrecht, Die Hymnen des Rig Veda, $2^{\text {nd }}$ ed., Bonn 1877, Vol. I, p. 374; Rg Veda VIII, 100, 12b; Rg Veda X, 68, 11a, both in Th. Aufrecht, Die Hymnen des Rig Veda, $2^{\text {nd }}$ ed., Bonn 1877, Vol. II, pp. 201 and 361 .

${ }^{27}$ Rg Veda IV, 17, 13c, in Th. Aufrecht, Die Hymnen des Rig Veda, $2^{\text {nd }}$ ed., Bonn 1877, Vol. I, p. 291; 'Blitzstein' in Rig-veda. Ubersetzt und mit kritischen und erlauternden Anmerkungen, I, trans. by H. Grassmann (Leipzig: F. A. Brockhaus, 1876), p. 125; A. A. Macdonell, Vedic Mythology (Straßburg: Karl J. Trübner, 1897), p. 22.

${ }^{28} \operatorname{Rg}$ Veda X, 45, 8b, in Th. Aufrecht, Die Hymnen des Rig Veda, $2^{\text {nd }}$ ed., Bonn 1877, Vol. II, p. 336. 
Hestia-Vesta, one should expect to find in the ancient Indian mythological and/or religious literature at least an important clue to the presence of such distinctive features [author's italics]. These are actually present in the same Rg Veda and in the Śatapatha Brāhmana ${ }^{29}$, too, a religious text written around the eighth century BCE. Being a compendium of descriptions of procedures related to the Vedic sacrificial rituals, this document should have the same legacy of wisdom as the Rgvedic hymnological corpus which seems a safe vestige of the antiquity of the tradition of wisdom to which both the above-mentioned features should belong - a background which dates, in my opinion, in all probability to the Common Indo-European period.

The mirroring of heaven and earth in theology concerning the Vedic Agni is absolutely perspicuous in another Vedic hymn, the 44th of Book VIII, where the couplets 15-17 read:

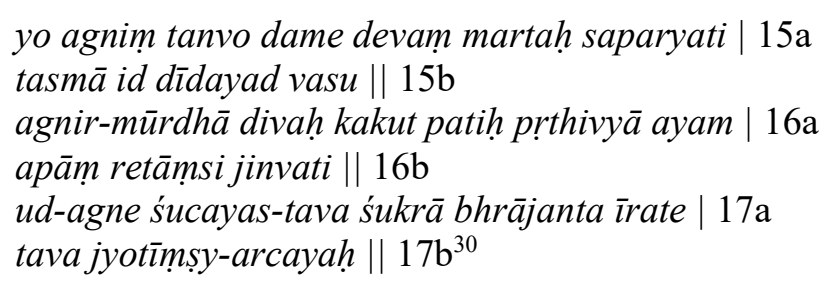

The mortal man who serves the god Agni within his own abode, for him he causes wealth to shine.

Agni is the head and the top of heaven, the master of the earth is he: he quickeneth the flowing waters' seed.

Upward, o Agni, rise thy flames, pure and brilliant, thy lustres effulgences.

The intimate connection between the celestial sphere and the globe is given unequivocally in 16a, where, in the syntactic adjacency, the expressions ' $m \bar{u} r d h \bar{a}$ divah kakut' and 'patih prthivyā' are juxtaposed, that is, respectively, 'the head and the top (kakud, related to Latin cacumen) of heaven' and 'the Lord of the earth': the heavenly connotation of fire binds well to the terrestrial one, which is connected to

${ }^{29}$ The Satapatha-Brahmana, according to the text of the Mâdhyandina school, translated by J. Eggeling, Sacred Books of the East, Vols. 12, 26, 24, 37, 47 (Oxford: Clarendon Press, 1882-1900).

${ }^{30} \mathrm{Rg}$ Veda VIII, 44, 15, 16, and 17, in Th. Aufrecht, Die Hymnen des Rig Veda, $2^{\text {nd }}$ ed., Bonn 1877, Vol. II, p. 144. 
sacrifice, and this cannot but recall both the Philolaic Hestia, that was considered to be the centre of the sidereal Cosmos, and the Ovidian Vesta, believed as 'the same thing of the earth' [author's italics]. This connection may also constitute a parallel with the Vestal who cared to keep the sacred fire lit in the fireplace placed inside of Aedes and the Indian priest who 'served' (saparyati), and actually dedicated himself to paying special attention to the worship of the sacred fire, namely sacrificial [author's italics]. The consequent benefit of devotion was to cause wealth to 'shine'. Hence, the term vasu (<*vas- 'shine', see ușās 'dawn', Greek है $\alpha \rho,\left({ }^{*} F \varepsilon \sigma \alpha \rho\right)$ 'spring', Latin ver 'id.') corresponds to the Latin dìvitiae, whose root *dīv- (< IE *dey-w-, see divves 'rich', dìvus ' $g o d$ ', dìus 'heavenly') is definitely related to the Sanskrit $d \bar{l}-(<\mathrm{IE} *$ dey, see Latin dīes (*dīes) 'day') of the causative verb form, dìdayat, according to an usual semantic shift 'beautiful $>$ rich'. Agni is, therefore, the giver of wealth and well-being; his fire keeps alive those who care for him, citizen or State, as it was for the hearth of Hestia-Vesta, the nominal root of which is precisely that of vasu. It is clear, then, that there was, in ancient times, in the historical Indo-European peoples and presumably in those prehistoric, a conceptual network that connected, in a structure, the celestial fire, its luminosity, the terrestrial hearth, and material well-being according to a precise 'vital ideology' in which were also included domestic pantry (penus) understood also as a personal 'life insurance'.

Another passage in the $R g$ Veda offers an astronomical system that could be called outright 'agnicentric', entirely homologous to the pyrocentric one professed by Philolaus. ${ }^{31}$ In fact, in the second hymn of Book III in the couplets 13-14 it is stated:

\author{
rtāvānam yajñiyam vipram-ukthyam-ā yam dadhe mātariśvā divi \\ kșayam |13a \\ taṃ citrayāmam harikeśam-ìmahe sudītim-agnim suvitāya \\ navyase || $13 b$ \\ śucim na yāmann-ișiram svardṛśam ketum divo rocanasthām- \\ ușarbudham |14a \\ agnim mūrdhānam divo apratișkutam tam-īmahe namasā vājinam \\ brhat $\| 14 \mathrm{~b}^{32}$
}

\footnotetext{
${ }^{31}$ Quoted in Aristoteles, De caelo 293a.17-b.32, in Huffman 1993, pp. 231-32.

${ }^{32}$ Rg Veda III, 2, 13-14, in Th. Aufrecht, Die Hymnen des Rig Veda, $2^{\text {nd }}$ ed., Bonn 1877, Vol. I, p. 220.
} 
16 Hestia: The Indo-European Goddess of the Cosmic Central Fire'

To Agni, faithful to the law, holy, wise, worthy of praise, which Mātariśvan had established, living in the sky,

to him, whose run is splendid, gold-haired, excellently bright, we get closer for a new prosperity;

as pure and swift of course, beholder of light, who dwells in the bright firmament as a sign of the celestial vault, who to wakes at dawn,

Agni, head of the sky, unstoppable; him, vigorous, we approach with great tribute.

The text combines, as usual, a religious quality and a sidereal one, because it defines the Indian fire god with certain terms related to his sacral sphere and, in other respects, in reference to astronomical phenomena in a close succession of sentences, so that it seems obvious that the two language levels connoting the deity are closely linked and mutually essential. First, Agni is 'sacred' (yajñiya, from the root yaj'worship'; see Greek órvós 'id.'), meaning he is the personification of the sacrificial fire [author's italics] ${ }^{33}$, since his actions conform to enforceable rules of the rite (rtāvan, by rta 'order' 'law', see atin ritus). However, above all, his 'dwelling is in heaven' (divi kșaya), a construct that closely resembles that of Stobaeus' description meaning 'house of Zeus' ( $\Delta$ iò $\varsigma$ oĩ $\varsigma \varsigma$ ) and referring to the Hestia-central cosmic fire of Philolaus ${ }^{34}$, if one considers that the Greek theonym for the god of Lightning had an original meaning of 'Shining Sky'. The brightness of the heavenly light is indeed a leitmotiv which is pervasive throughout the song: the god is represented as 'blond' (hari-keśa) since he radiates a bright light (su-dìti, letter; 'well-shining' from the root $d \bar{l}$ - 'shine', see Latin diēs 'day', 'sky', Dies-piter Iuppiter") and he looks in the light (svar-dr'śa) and experiences a beautiful ride (citra-yāma) in sidereal space. It is remarkable how Agni is here described as a 'sign' or 'mark' (ketu) of heaven (divah) in his stay in the bright celestial vault (rocanasthā, from ruc-, related to Latin lucēo 'shine', lux 'light', Greek $\lambda \varepsilon v \kappa o ́ \varsigma$ 'white'), as if the god would mark a precise and relevant geometrical place in the firmament - namely, the central point (madhyam). $\mathrm{He}$, as a

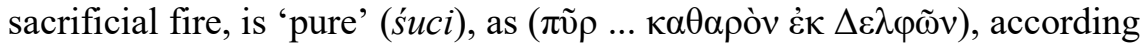

33 A. Michaels, Homo Ritualis. Hindu Ritual and Its Significance for Ritual Theory (New York: Oxford University Press, 2016), pp. 126-36, 187-96 and 230-49; see also, F. Staal, Agni: The Vedic Ritual of the Fire Altar, I-II (Delhi: Motilal Banarsidass 1984).

${ }^{34}$ Stobaeus, Anthologium, Eclogae I, 22, 1d, 1-17, in Huffman 1993, p. 237. 
to Plutarch ${ }^{35}$, the eternal flame of the sanctuary of Apollo at Delphi; and is 'swift in his run' (yāmann-ișira) through the sky, as was the Greek god

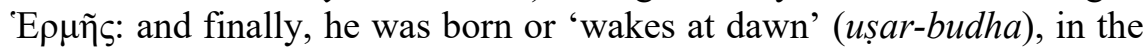
morning hour when the fire of sacrifice was kindled.

The physical quality of the fire of sacrifice is eminently its exceptional refulgence, an 'emic' tract that connects it in a close relationship to the god, 'Shining Sky', namely Dyaus (Pitār), who is none other than the ancient Vedic god of Lightning whom we know to be related to the Greek Zev̀s ( $\pi \alpha \tau \eta \dot{\eta} \rho)$ and the Roman I $\bar{u}$-(piter) [author's italics]. Not only is the fixed point in which is located this celestial sphere bright, but also its run through is bright. It seems as if Agni, the centre and the circular perimeter of the Cosmos that he enclosed, containing it within his fire, is simultaneously the igneous and aethereal element of Philolaus. This comparison is not at all risky, if you thoroughly analyse the contents of the following couplets:

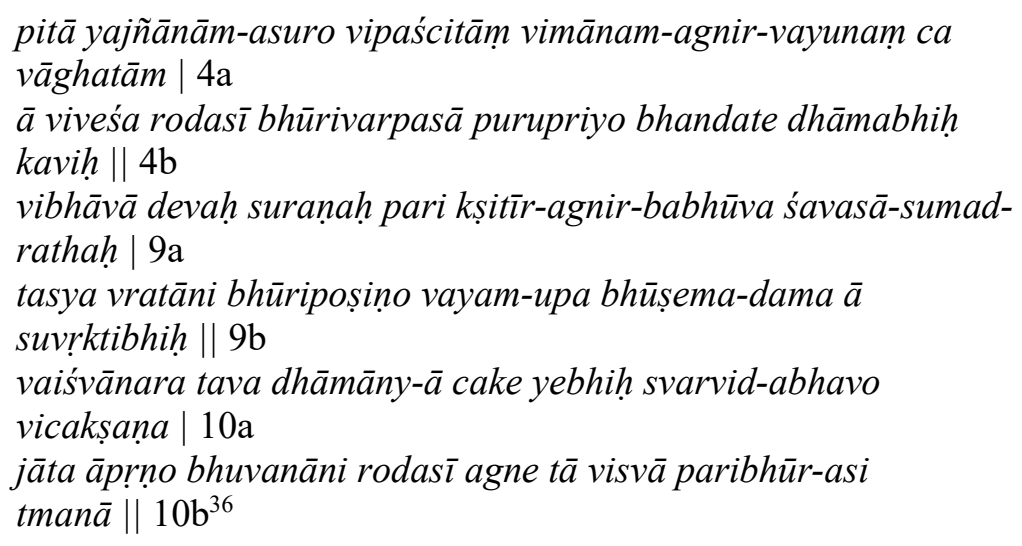

Father of sacrifices, Asura of the inspired, measure and rule of the establisher of a sacrifice,

Agni hath entered the heaven and the earth in many forms, sage much loved is happy in his dwellings.

Agni, the resplendent god, joyful, with his chariot surrounded the earth with strength;

\footnotetext{
${ }^{35}$ Plutarch, Aristides XX, 4, 1-6, 6, in Plutarch, Lives, II: Themistocles and Camillus. Aristides and Cato Major. Cimon and Lucullus, translated by B. Perrin (London: Loeb Classical Library, 1968 [repr. 1914]), pp. 276-77.

${ }^{36} R g$ Veda III, 3, 4, 9 and 10, in Th. Aufrecht, Die Hymnen des Rig Veda, $2^{\text {nd }}$ ed., Bonn 1877, Vol. I, pp. 221-22.
} 
let us try to provide the observance of multi-nourisher in his house with beautiful laudations.

I wish thy dwellings, Vaiśvānara, with which thou, farsighted, are in search of light;

generated, thou filledst the heaven and the earth: all this, Agni, hast thou surrounded with thyself.

In these verses, the celestial feature of Agni is repeated several times; he, however, is defined as 'father of the sacrifices' (pitā(r) yajñanām), confirming his pre-eminent function as the cultural tool operator: the god gives the measure and the way (vayunam, which has the same root $v \bar{l}$ - of veti 'go', compare Latin ve-nāri 'go hunting', German weida, Weide, weiden 'graze') to follow for those who lead (väghat, corradical of vahati 'carries', 'leads', see Latin vehō 'id.', vehiculum 'vehicle', wagon', Greek ö $\chi 0 \varsigma$ ( $\left.{ }^{*} F o \chi 0 \varsigma\right)$ 'id.', slav. vesti < IE *we ${ }^{\mathrm{h}}$-) the ritual with which the sacrifice itself is made. Verse 4a contains many words that indicate movement, as can be seen from vimāna, which, besides being a medical technical term suitable to indicate the science of the right size and proportion, also identifies the legendary Indian gods' chariot going through the heavenly airspace, but sometimes also serving as their 'throne': the Rgvedic syntagma, vimannam-agnir, would then ideally be

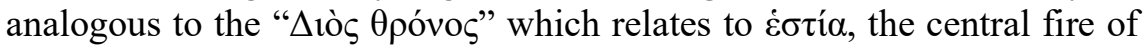
the pyrocentric system of Philolaus. In fact, if Agni occupied the central point of the Indian Cosmos, from the above-mentioned Rgvedic verses, it seems that the fire god resided even in an extended 'perimeter zone' of the Cosmos itself, thus making his dwelling place within the Universe at the same time fixed as a 'throne' and automotive as a quick 'chariot'. Ultimately, with this $v i-m \bar{a} n-a$, he would appear as to measure (from the verb stem vi-mān- 'measure', see Latin men-sura) the entire circumference of the celestial sphere, surrounding it all with his igneous element. This is a hypothesis which I'm going to prove in due time. ${ }^{37}$

Within the parameters of what has been detected, it requires a reflection on the facts described: the strong formal and 'emic' concordances between the Vedic cosmology concerning the god Agni and the pyrocentric system of Philolaus are so numerous that they cannot be attributed to chance. For all we know, moreover, only the Greek and

37 M. De Martino, Le divine gemelle celesti. Sacertà del Fuoco centrale e semantica dell'Aurora nella religione indoeuropea (Lugano: Agorà and Co., 2017).

Culture and Cosmos 
Indian speculations have led to the creation of such a complicated ideology on the sacredness of Fire. We are not aware of other 'primitive' cultures that have laid the igneous element within a broad astronomical structure wherein the concepts concerning Centre and Circularity were the fundamental characteristic features [author's italics].

The remarkable and cogent structural congruences of such mythological and cultural themes regarding fire as sacrificial element confirm our conviction that one has entered another important piece in the complex mosaic of religious Proto-Indo-European framework. Accordingly, once having made sure of an Indo-European ancestry even regarding the conceptual material that has been handed down as the 'mythological tinsel' of the Pythagorean-Philolaic pyrocentric system, we feel entitled to make a further and more profound analysis in the future in order to better understand the 'philosophical', or rather, theological reasoning that had conceived it. 